
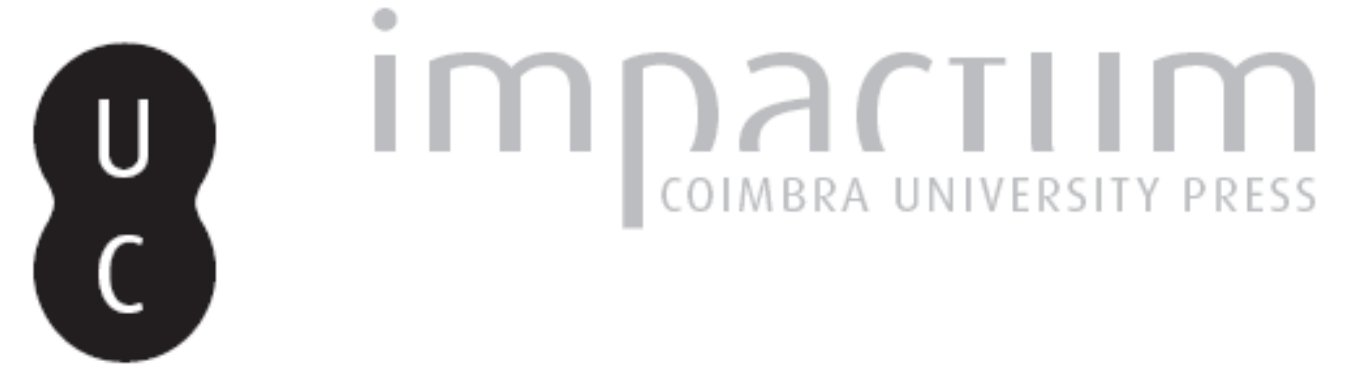

\title{
A Cobertura Midiática e seus Efeitos para a Desconfiança na Política
}

\author{
Autor(es): Vieira, Aletheia Patrice \\ Rodrigues
}

Publicado por: Imprensa da Universidade de Coimbra

URL persistente:

URl:http://hdl.handle.net/10316.2/43202

DOI:

DOI:https://doi.org/10.14195/2183-6019_5_5

Accessed : $\quad$ 26-Apr-2023 03:48:52

A navegação consulta e descarregamento dos títulos inseridos nas Bibliotecas Digitais UC Digitalis, UC Pombalina e UC Impactum, pressupõem a aceitação plena e sem reservas dos Termos e Condições de Uso destas Bibliotecas Digitais, disponíveis em https://digitalis.uc.pt/pt-pt/termos.

Conforme exposto nos referidos Termos e Condições de Uso, o descarregamento de títulos de acesso restrito requer uma licença válida de autorização devendo o utilizador aceder ao(s) documento(s) a partir de um endereço de IP da instituição detentora da supramencionada licença.

Ao utilizador é apenas permitido o descarregamento para uso pessoal, pelo que o emprego do(s) título(s) descarregado(s) para outro fim, designadamente comercial, carece de autorização do respetivo autor ou editor da obra.

Na medida em que todas as obras da UC Digitalis se encontram protegidas pelo Código do Direito de Autor e Direitos Conexos e demais legislação aplicável, toda a cópia, parcial ou total, deste documento, nos casos em que é legalmente admitida, deverá conter ou fazer-se acompanhar por este aviso.

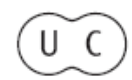


revista de comunicação,

jornalismo e espaço público

\section{5}

Periodicidade

Semestral

Imprensa da Universidade de Coimbra

Coimbra University Press

\section{mediapolis}

crises e os processos comunicativos

crisis and communicative process

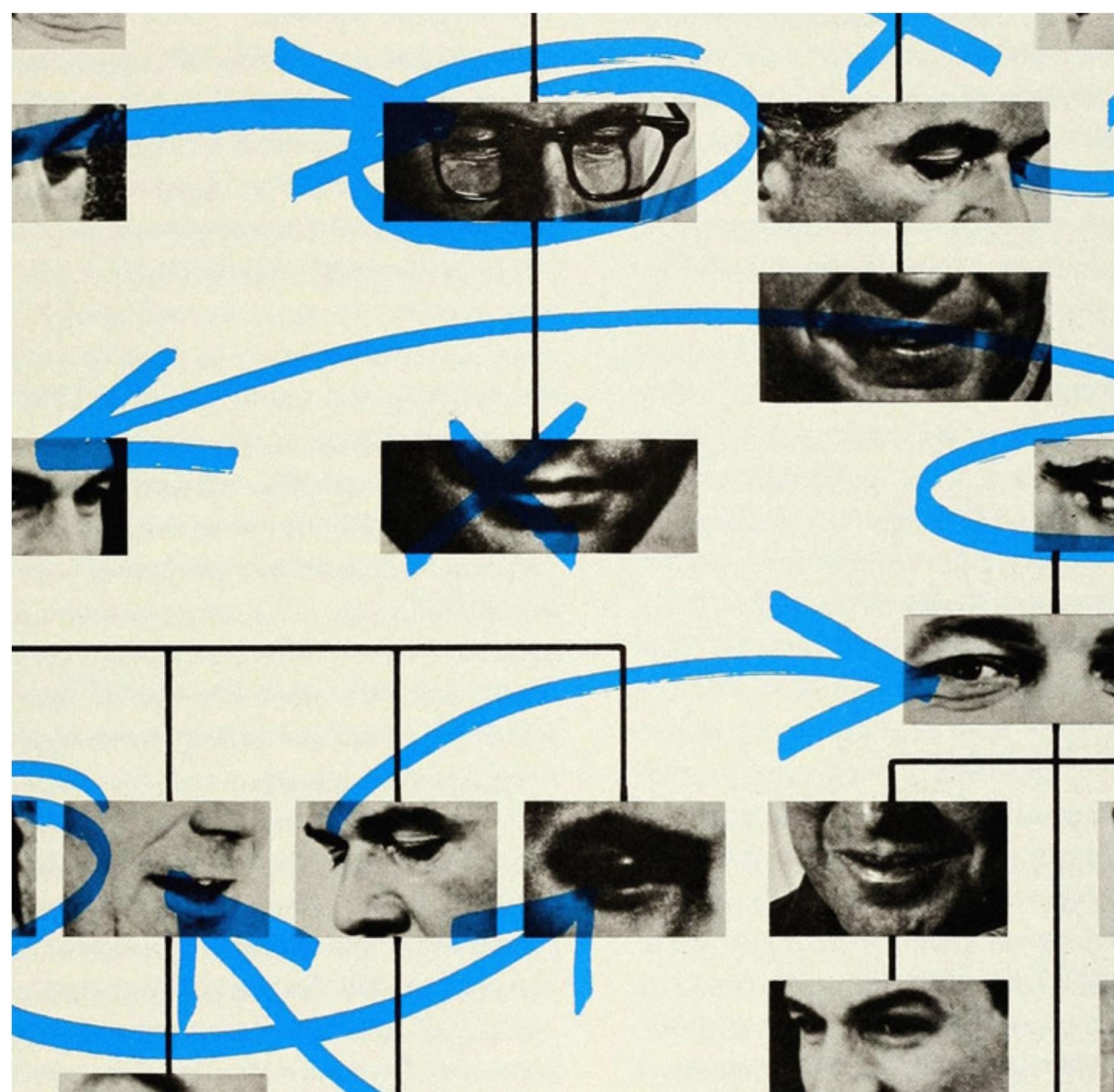




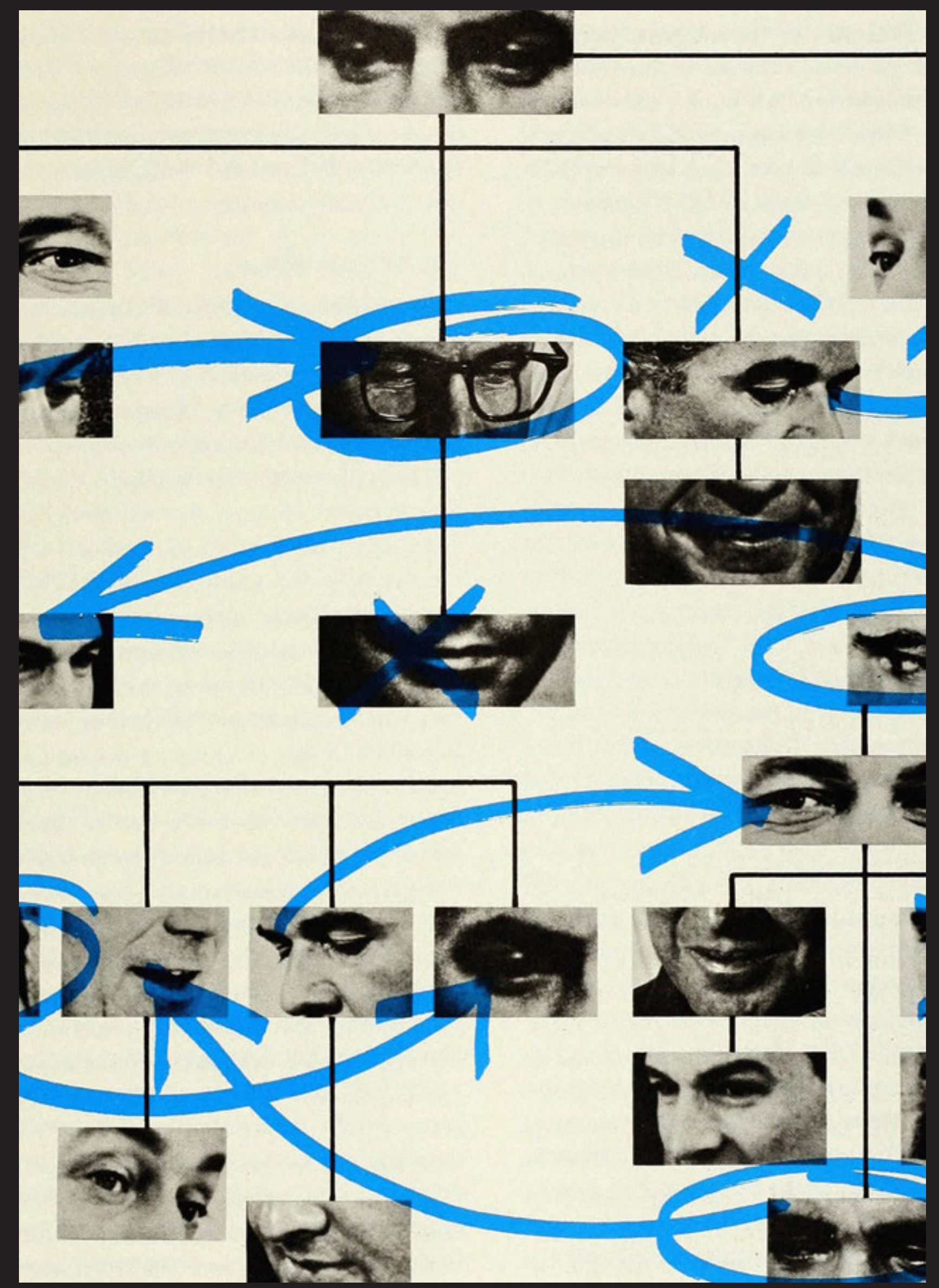




\section{A Cobertura Midiática e seus Efeitos para a Desconfiança na Política}

Media Coverage and its Effects on Distrust in Politics

\section{Resumo:}

$\mathrm{O}$ artigo trata da relação entre o discurso midiático e a crise de representatividade no modelo democrático. Partimos da hipótese de que, ao se colocarem entre as instituições defensoras do interesse público no contexto de liberdade de expressão, os veículos midiáticos contribuem para a desconfiança da população na política e nos políticos. Isso também acontece porque o modelo democrático não privilegia a participação popular nas tomadas de decisão.

Palavras-chave: corrupção; crise; escândalo político; democracia; desconfiança; mídia

\section{Abstract:}

This article deals with the relation between the media discourse and the crisis of representativeness in the democratic model. We start from the hypothesis that, located among the institutions that defend the public interest in the context of freedom of expression, media vehicles contribute to the public distrust in politics and politicians. This is also because the democratic model does not privilege popular participation in decision-making.

Keywords: corruption; crisis; political scandal; democracy; distrust; media 


\section{Introdução}

É possível fazer uma relação entre o discurso midiático sobre corrupção e a crise de representatividade? $\mathrm{O}$ objetivo do artigo visa responder a essa pergunta a partir da combinação das teorias de comunicação e do jornalismo com a literatura da Ciência Política acerca dos modelos democráticos e seus impactos na participação política dos cidadãos.

Do ponto de vista da comunicação, conforme Wolf (1987), Traquina (2005) e Lima (2004), os efeitos da mídia são de longo prazo - isto é, constituem-se fundamentalmente nas representações, no agendamento, na definição da relevância de temas e abordagens, na construção do que é o senso comum. O efeito torna-se cumulativo e sugere que as mesmas representações sobre vários temas, inclusive a política, estão sistematicamente presentes na mídia e constituem o imaginário coletivo.

Os autores Rosavallon (2008), O’Donnel (1991) e Chandhoke (2005) traçam um panorama da expansão dos modelos democráticos, principalmente quanto ao sufrágio universal, que concentra a expectativa dos eleitores em pessoas e não em partidos e ideologias. Mas, apesar da decisão soberana daqueles aptos a votar ser essencial numa democracia, a distância da população nas tomadas de decisão dos governos e na elaboração de políticas públicas contribuíram para a crise de representatividade.

Outra característica importante gerada por esse processo é a ausência de uma prestação de contas (accontability) que possa ser mais acessível. Os veículos midiáticos têm assumido o papel de cobrá-la ao investigar, por exemplo, casos de corrupção.

Segundo Thompson (2002), quando o caso envolve muito dinheiro e pessoas importantes, os escândalos político-midiáticos podem emergir e dar visibilidade às ações realizadas num ambiente privado ou escondido. Esses desvios éticos contribuem para a crise de representatividade e aumentam a desconfiança na política.

A redução da credibilidade da população/eleitores na política e nos políticos é tema de vários trabalhos acadêmicos, como visto em Moisés e Carneiro (2008), Guazina (2011) e nos levantamentos realizados pelo Consórcio Latinobarômetro, que tem feito correlação entre a desconfiança dos cidadãos e a democracia. Também não é possível pensar sobre confiança e representatividade fora do contexto midiático, se compreendermos a mídia como ator central na democracia e local de construção da confiança nas instituições.

O artigo é essencialmente teórico, tendo em vista a abrangência do tema, e apresenta algumas conclusões da dissertação de mestrado da autora, que aborda a narrativa da revista Veja sobre o político José Dirceu, ex-ministro da Casa Civil do Brasil (governo Luiz Inácio Lula da Silva), analisado como personagem no escândalo político conhecido como Mensalão, ocorrido nos anos 2000.

A dissertação levantou reflexões sobre os escândalos político-midiáticos, a corrupção e a desconfiança nos regimes democráticos, a partir 
da trajetória de ascensão e queda do personagem.

\section{A crise na democracia representativa}

Entende-se por democracia indireta ou democracia representativa todo sistema político em que cidadãos elegem seus representantes por meio do voto. Aos representantes é conferida o poder de tomar decisões em nome do povo. Esse modelo, apesar de ser considerado justo por envolver a sociedade na escolha de seus governantes, está em crise.

De acordo com Rosavallon (2008), o poder do voto direto ganhou aceitação imediata nos modelos de governos democráticos liberais. A ideia de que as pessoas têm o poder de escolha não seria questionada, pois a prevalência do voto da maioria é a essência da democracia, em contraste aos regimes autoritários. Entretanto, ao longo de décadas, apenas o voto não foi suficiente para consolidar a confiança dos eleitores em seus governantes. Unido a isso, perderam-se também alguns critérios de julgamento da qualidade

\section{O artigo é}

essencialmente

teórico, tendo em

vista a abrangência

do tema, e

apresenta algumas

conclusões da

dissertação de

mestrado da

autora, que aborda

a narrativa da

revista Veja sobre o

político José Dirceu da democracia no país, uma espécie de acomodação dos representados. Denúncias de corrupção, promessas de campanha não cumpridas e a falta de identificação ideológica com os partidos políticos podem ser elencados como motivos para essa descrença.

Portanto, as novas formas de democracia precisam de ser elaboradas, com vista à descentralização de poder. O modelo tradicional de voto maioritário dos países acabou por limitar a expressão popular. Rosavallon (2008) acrescenta que, apesar da democracia indireta significar o voto da maioria, esses eleitores não têm participação nas decisões dos políticos eleitos.

Uma das possíveis soluções para a resolução da crise seria a implantação da democracia participativa, modelo em que a população opina e delibera sobre as decisões políticas, que seria um passo além da democracia delegativa, termo usado por O’Donnel (1991) para designar a concentração de poder e responsabilidades nos políticos. $\mathrm{O}$ voto permaneceria sendo o instrumento de escolha dos representantes, pelo que a democracia participativa 
qualificaria as escolhas dos eleitores por políticas públicas e decisões que beneficiem o interesse coletivo.

Com a deficiência da participação popular nos mandatos políticos, outros poderes de supervisão se fortaleceram, como enumerados por Rosavallon (2008):

"Cinco tipos existem hoje: o controle parlamentar do executivo, combinado com poderes de investigar; opinião pública, que é polarizada e expressa de uma forma difusa através da mídia; intervenção crítica por partidos da oposição; movimentos e organizações de carácter social; e ad hoc instituições democráticas" (Rosavallon, 2008: 301).

Chandhoke (2005) e O'Donnel (1991) realizaram pesquisas sobre a Índia e a América Latina, respectivamente, e dão exemplos de locais que enfrentam graves problemas sociais, mesmo com a implantação de modelos democráticos que dependem do voto e onde os governos e mandatários não promoveram, de forma eficaz, a participação popular na formulação de políticas públicas.

Chandhoke (2005) constatou que a população indiana não obteve significativo retorno em forma de políticas públicas que considerassem as suas necessidades básicas. A decepção, causada pela manutenção da pobreza extrema, da fome, da falta de saneamento básico, da educação precária, da doença e da desigualdade de oportunidades, provocou o descrédito na política: "Os partidos políticos esgotaram a sua capacidade de representar as aspirações de seus colégios eleitorais, tornaram-se hierárquicos, burocráticos e rígidos, e eles tendem a seguir a lógica política e impulso do poder" (Chandhoke, 2005: 311).

Conforme a autora, o objetivo da institucionalização generalizada do sistema partidário competitivo seria resolver o dilema da democracia no século XX: a impossibilidade de estabelecer uma relação entre o cidadão e o Estado nas sociedades grandes e complexas. Mas, segundo a pesquisa, essa transição não aconteceu na Índia de forma satisfatória: $41 \%$ dos entrevistados disseram que as suas necessidades básicas não foram atendidas, pois os representantes não "apresentam os interesses dos seus eleitores em fóruns de formulação de políticas" (Chandhoke, 2005: 313).

Portanto, na visão de Chandhoke (2005), todo governo democrático é moralmente obrigado a assegurar uma vida digna para o povo, atender as suas necessidades e apresentar fielmente os interesses para que os seus constituintes obtenham isso. Caso isso não aconteça, o cidadão comum vai, cada vez mais, tratar a política e os políticos como irrelevantes, pois, sem condições minimamente dignas, essas pessoas não conseguem prosseguir com os seus planos de vida.

Chandhonke (2005) completa que além de não conseguirem cumprir a responsabilidade para com as pessoas, os partidos políticos se degeneraram rapidamente para máquinas sedentas de poder, não representativos e corruptos.

A própria determinação do sistema para a manutenção de poder contribui para o afastamento dos eleitos de suas 
bases eleitorais e de militância. Isso tem acontecido no Brasil e afetou o Partido dos Trabalhadores (PT), de centro-esquerda, tornando-se, porém, dependente de alianças com agremiações consideradas de direita para permanecer na Presidência da República. Nem essas alianças conseguiram evitar o impeachment da ex-presidente Dilma Rousseff, em 2016, por exemplo. A maioria dos partidos da base de apoio ao governo votaram pelo afastamento da mandatária. Diante disso, podemos afirmar que as alianças partidárias no Brasil não têm priorizado os interesses da população e sim os particulares: " $O s$ representantes peneiram interesses articulados, selecionam aqueles que eles consideram digno de representar, priorizam as agendas que aparecem mais viáveis para eles sobre os outros" (Chandhoke, 2005: 324).

Uma das consequências dessa relação de afastamento entre o representante e o representado, além do descrédito na capacidade dos políticos e dos partidos por parte dos eleitores, é o enfraquecimento da democracia: quando os cidadãos recorrem
A própria

determinação do

sistema para a

manutenção de

poder contribui

para o afastamento

dos eleitos de suas

bases eleitorais e

de militância. a contatos personalizados para resolver seus problemas pode-se abrir brecha para o patrimonialismo e para a desmobilização popular em nome de objetivos comuns. No Brasil, isso ocorre principalmente nos episódios de compra de votos, troca de favores ou mesmo chantagens.

Em relação à América Latina, O’Donnel (1991) propõe uma tipologia de democracias dentro dos padrões da execução de políticas públicas, e considera que o modelo adotado nos países que enfrentaram regimes autoritários, a exemplo do Brasil, culminou em democracias delegativas. Como as heranças dessas ditaduras resultaram em profundas crises socioeconômicas, prevaleceu o discurso organicista e individualista, que isola o Presidente da República, o responsável pelas decisões certas ou erradas, principalmente quando se trata de política econômica.

"Quem ganha uma eleição presidencial é autorizado a governar o país como lhe parecer conveniente e, na medida em que as relações de poder existentes permitam, até o final do seu mandato. 
O presidente é a encarnação da nação, o principal fiador do interesse nacional, o qual cabe a ele definir. $\mathrm{O}$ que ele faz no governo não precisa guardar nenhuma semelhança com o que ele disse ou prometeu durante a campanha eleitoral" (O’Donnel, 1991: 30).

O’Donnel (1991) também defende a partilha de responsabilidades, ainda mais porque, na democracia delegativa, o presidente não seria obrigado a prestar contas do mandato de forma horizontal: "Depois da eleição, espera-se que os eleitores/delegantes retornem a sua condição de espectadores passivos, mas quem sabe animados, do que o presidente faz" (O'Donnel, 1991: 31).

A democracia delegativa cria um cenário de centralização de poder em cima do presidente da República, alguns eleitos como salvadores da pátria, fortes e corajosos. No caso do Brasil, Fernando Collor de Melo, o presidente eleito em 1989, após a Ditadura, se apresentou à mídia como o "caçador de marajás", termo utilizado para designar quem beneficiava do
Estado para interesses privados. De acordo com Conti (1999), o legado de Collor resultou em acusações de corrupção e planos econômicos que fracassaram, originando o impeachment.

\section{A Representação}

\section{Midiática da Política}

Segundo Miguel (2010), mesmo no século XXI, ainda vigora o senso comum de que os políticos não são confiáveis, gostam de mordomias e se utilizam da corrupção para conquistar seus objetivos. "Essa percepção está presente em países ricos e pobres, em velhas e novas democracias" (Miguel, 2010: 223). $\mathrm{O}$ autor acrescenta que vários indicadores apontam para o declínio da confiança na política em ambientes democráticos no ocidente, que conciliam valores como a soberania popular com "a falta de fé nos mecanismos institucionais" (Miguel, 2010: 223). Se considerarmos que a mídia é uma das instituições partícipes do ambiente democrático, podemos concluir que o senso comum apresentado por Miguel (2010) reflete a representação midiática da política.
No Brasil, a cobertura política com prioridade é o padrão de cobertura noticiosa dos grandes veículos de mídia. Mesmo quando o país está vivenciando momentos de ascensão econômica e relativa tranquilidade aparente nas relações político-partidárias, há um pequeno exército de repórteres que procura possíveis falhas individuais de políticos ou de servidores públicos, principalmente daqueles que representam um governo contrário ideologicamente aos interesses comerciais das empresas de comunicação. Este comportamento é citado por Waisborn (2000) como jornalismo "cão de guarda", popularizado na imprensa dos Estados Unidos a partir do século XIX, que se tornou característico nos países latino-americanos que se democratizaram após ditaduras militares.

A pesquisa de Rehbein (2015) aponta para essa tendência. O levantamento traz 1768 notícias dos jornais brasileiros Folha de São Paulo, $O$ Estado de São Paulo e O Globo, nos meses de maio de 1995, 2001, 2003 e 2005, anos em que o país alternou momentos de tranquilidade e crise na política. Com $44 \%$, as denúncias 
divulgadas pelas editorias de política aparecem em primeiro lugar, como manchete de primeira página. No mesmo quesito, as ações do governo aparecem com $9 \%$ e os protestos e manifestações populares com 8\%. Entre as fontes, os detentores de cargos políticos são os mais ouvidos, com $49 \%$. Rehbein (2015) constatou, porém, que só em 581 matérias (33\%), a posição contraditória foi consultada.

A partir da pesquisa de Rehbein (2015) e dos estudos de Waisborn (2000), faz-se necessária a atenção para os enquadramentos midiáticos que priorizam os bastidores e escândalos da política partidária no Brasil, em detrimento a outros assuntos que afetam diretamente a vida da população, entre eles, o racismo, o machismo, a homofobia, a falta de saneamento básico e de outros serviços como saúde e educação.

Por isso, para Tuchman (1978: 184), "as notícias não refletem a sociedade. Elas ajudam a constituir um fenômeno social partilhado, dado que, no processo de descrever um acontecimento, as notícias definem e dão forma ao mesmo". A autora também aponta que os jornalistas possuem maneiras específicas de contar histórias e essas narrativas possuem códigos reconhecidos pelos destinatários.

Sobre a questão, Traquina (1993: 176) afirma que "as notícias registram as formas literárias e as narrativas utilizadas pelos jornalistas para organizar o acontecimento", o que nos leva a discorrer sobre o enquadramento midiático.

O enquadramento (frame) é a linha orientadora das notícias, conforme Tuchman (1993). Entman (1993) aprofunda o conceito, dizendo que a mídia torna salientes alguns aspectos da realidade, de forma que eles possam ser interpretados, diagnosticados, e avaliados por meio de prescrição moral. Ou seja, em determinados acontecimentos, o julgamento do político envolvido em casos de corrupção, por exemplo, é realizado primeiro pela mídia e, posteriormente, pelas autoridades policiais e judiciais.

Segundo Guazina (2011), existe uma relação entre o enquadramento da mídia na cobertura sobre escândalos (que está relacionada com os interesses ideológicos das empresas de comunicação) e a adversidade entre jornalismo e política, também fomentada pela conduta individual dos profissionais de comunicação, que se apresentam como defensores da ética, da lisura e do interesse público.

Guazina (2011) explica que o jornalismo assume o papel de porta-voz do "interesse público" com o objetivo de garantir que possui credibilidade perante a sua audiência e, dessa forma, assegurar o seu poder dentro da sociedade. Esse poder é usado como contrapeso em relação ao poder dos governos nas democracias: “[O jornalismo] é um porta-voz que o público não elegeu e com o qual se relaciona de forma mediada, com base em uma relação de consumo" (Guazina, 2011: 25).

Em contrapartida, alguns autores consideram que a mídia é um pilar importante da consolidação da democracia no Brasil e tem cumprido o seu papel ao denunciar desmandos políticos e casos de corrupção. Segundo 
Matos (2008: 295), o jornalismo político se profissionalizou e tem mantido padrões de qualidade "como o profissionalismo na reportagem política, o equilíbrio e a crítica política".

Na visão de Bucci (2000), apesar de os grandes veículos de mídia terem apoiado inicialmente a Ditadura Militar no Brasil, a democracia atual do país deve muito ao jornalismo. “ $\mathrm{O}$ jornalismo consiste em publicar o que os outros querem esconder mas que o cidadão tem direito de saber" (Bucci, 2000: 42).

Além disso, o autor aponta que os jornalistas enfrentam muitas dificuldades nas redações e que em todas as opções editoriais, alguém perde e alguém ganha. "Uma série de resoluções no cotidiano jornalístico são resoluções solitárias. Não há tempo para debatê-las, não há condições técnicas de ouvir todas as opiniões, ponderá-las, voltar a avaliar". (Bucci, 2000: 43).

A partir das leituras feitas, podemos concluir que o principal motivo da decepção dos eleitores com os seus mandatários é a ausência de resolução de problemas básicos e esse é um dos pretextos que a mídia utiliza para justificar o enquadramento negativo utilizado para representar a política, principalmente em situações de crise e escândalos. O que está por detrás do descrédito na democracia representativa não é exclusivamente a investigação jornalística de atos transgressores de homens públicos, mas a ausência de participação popular no sistema democrático.

Alheada das decisões políticas, grande parte dessa população só tem contato com assuntos relacionados à política por meio da mídia, que privilegia os aspectos negativos da política partidária em sua programação, contribuindo dessa forma para desconfiança e aversão da política por parte dos cidadãos. Esses temas serão detalhados no tópico a seguir.

\section{A desconfiança na}

\section{política e o papel da mídia}

Os pesquisadores Moisés e Carneiro (2008) indicam que o Brasil ocupa o primeiro lugar em relação aos baixos índices de identificação partidária. A avaliação negativa do Congresso $\mathrm{Na}$ cional também vigora entre esses itens. No caso do Brasil, vários levantamentos, com o objetivo de medir a confiabilidade da população em diferentes instituições, apontam a prevalência da desconfiança da política. Conforme Warren (1999), a desconfiança é a atitude de descrédito ou de desmerecimento de alguém ou de algo.

Segundo dados do Instituto Latinobarômetro, divulgados em 2013, a população brasileira confia mais nos veículos de comunicação do que na classe política: 76,10\% dos entrevistados afirmaram ter pouca ou nenhuma confiança no Congresso Nacional. Porém, mais de $50 \%$ deles declarou ter muita ou alguma confiança nos jornais, rádio e TV.

Miguel (2010: 227) argumenta que haveria um círculo vicioso envolvendo a cobertura midiática sobre política, as expectativas do público e o comportamento dos políticos. Diante disso, os políticos sentem que não adiantaria assumir uma postura correta e voltada para o bem comum "pois sempre serão 
encarados como autointeressados e carreiristas. Os jornalistas saberiam que seus leitores esperam uma leitura neste diapasão".

Sobre o jornalismo político especificamente, Miguel (2010: 232) ressalta que os repórteres aprendem a especular quais os interesses e vantagens por detrás da realização de políticas públicas, por exemplo, ao invés de explicar ou avaliar quais seriam os seus efeitos positivos na população: “Nosso governo nos parece pior porque não faz o que os outros governos fazem e que os meios de comunicação não mostram". Na visão do autor, é um tipo de narrativa onde predomina a negatividade e a exigência por respostas rápidas, que prejudicam a qualidade das decisões políticas.

A desconfiança até pode ser positiva, de acordo com Moisés e Carneiro (2008), pela posição quase passiva da parte da população, que não tem acesso ou controle relativos ao funcionamento de um órgão público. Mas, quando em excesso, é prejudicial. Concordamos que os atos de corrupção ou desvio de dinheiro

\section{O que está}

por detrás do

descrédito na

democracia

representativa não

é exclusivamente

a investigação

jornalística de atos

transgressores de

homens públicos,

mas a ausência

de participação

popular no sistema

democrático. público precisam de ser elucidados e investigados pelo poder público e divulgados pela imprensa.

Mas a questão aqui problematizada é o enquadramento midiático que se dá em relação a uma situação mais ampla: a disseminação da desconfiança na política prejudica a democracia, desestimula os cidadãos a reivindicarem participação nos processos de tomada de decisão: "A centralidade da mídia decorre do poder de longo prazo que o conteúdo das comunicações tem na construção da realidade, através da representação que faz dos diferentes aspectos da vida humana" (Lima, 2004: 19).

Durante a cobertura de um escândalo midiático, por exemplo, no contexto de hegemonia e dominação midiáticas, as construções de realidade são acionadas na memória da audiência e reforçam a ideia de que todos os políticos são iguais, que ninguém será punido.

Lima (2004) acrescenta que a cobertura jornalística na América Latina tende a dramatizar os fatos noticiáveis, 
principalmente na televisão, resultado da ligação histórica e cultural da região às telenovelas e folhetins. Traquina (2005) classifica a dramatização e a personalização como valores-notícia de construção, essenciais para tornar o produto jornalístico acessível e atraente ao público.

O uso da personalização como valor-notícia no noticiário político faz todo o sentido em sistemas eleitorais presidencialistas, como ocorre na América Latina. Aliado à dramatização, a personalização contribui decisivamente para a construção do imaginário de generalização quanto à reputação dos políticos.

Para Waisbord (2000), as representações políticas estão se tornando cada vez mais desacreditadas pela população por influência da mídia, porque a política é tratada de forma hegemônica - o que pode levar o público a fazer associação direta da figura de todos os políticos com a corrupção.

Como dito anteriormente, a construção de uma narrativa dramática em torno dos escândalos políticos norteia a cobertura jornalística. É compreensível, a não ser que seja pelo simples sensacionalimo, que esse tipo de recurso seja utilizado em grandes reportagens, mais descritivas, sobre assuntos diversos ou mesmo tragédias, que mobilizam uma grande quantidade de pessoas Mas, como constatado em nossa dissertação de mestrado, essa linguagem é utilizada para prolongar a cobertura política, conferir efeito de sentido aos destinatários da mensagem e por interesses mercadológicos. Quanto mais caráter de espetáculo for dado ao noticiário político, maior a garantia de audiência e do exercício do poder dos grandes veículos de comunicação em influenciar decisões políticas, demissões e cassações.

Dependendo do tipo de denúncia, o escândalo político afeta um ou vários indivíduos que realizavam transgressões éticas e morais de forma obscura. Com a democratização no Brasil, uma das exigências da sociedade civil é a transparência nos atos daqueles que foram eleitos pelo povo ou que possuem caráter público em suas atuações.
A personalização dos atores envolvidos na denúncia ocorre por diversos fatores. Um deles é a importância de seus cargos na hierarquia do cenário político. Presidente da República, ministros, senadores e deputados federais são os que têm mais visibilidade. A situação piora quando aparece uma grande quantia em dinheiro (Thompson, 2002) oriunda de supostos esquemas ilegais de corrupção relacionadas a esses nomes: "Quanto mais personalizado é o acontecimento, mais possibilidades tem a notícia de ser notada, pois facilita a identificação do acontecimento em termos negativo ou positivo" (Traquina, 2005: 92).

O escândalo provoca conflitos na arena política, o que leva o jornalismo a construir enredos de acordo com o desenrolar dos acontecimentos. Dessa forma, os personagens começam a surgir na narrativa jornalística dentro de uma estrutura muito semelhante à dramaturgia: heróis, vilões, derrotados, vencedores ou injustiçados são algumas das funções dramáticas atribuídas aos atores envolvidos. A dramatização provoca reações emocionais na audiência. Por isso, é muito comum que inspire sentimentos de 
indignação, revolta, desconfiança ou até de admiração de personagens envolvidos. Mesquita (2003) aponta que as figuras heróicas e também anti-heróicas compõem os modelos de identificação das personagens jornalísticas e completa: “Os jornalistas gostam de propor imagens simplificadoras das pessoas" (Mesquita, 2003: 125).

Já Gomes (2007) associa a construção do personagem político à profissionalização das campanhas eleitorais após a redemocratização do Brasil. A biografia do candidato, seus desafios e aspirações são apresentados numa linguagem dramática, que é utilizada principalmente nos programas eleitorais produzidos para a televisão. No contexto do escândalo e da crise de imagem, o jornalismo procura desconstruir essas encenações, mas, para isso, também se apropria da linguagem dramática.

A composição do personagem político, na presença de um escândalo ou não, ocorre pela junção de várias características observadas pelos jornalistas: físicas, psicológicas, sociais, entre outras. A partir dessa observação, o enquadramento das matérias pode ressaltar "qualidades, forças, tendências, virtudes, programas ou poderes que tenham um impacto decisivo na cultura política e na mitologia de um país" (Meyer e Hinchman, 2008: 61).

Podemos exemplificar a construção dos personagens a partir de características acentuadas no enquadramento midiático com o episódio ocorrido durante o escândalo conhecido no Brasil como Mensalão do PT, um dos objetos de estudo da autora do artigo. Trata-se dos depoimentos dos deputados federais na época Roberto Jefferson (PTB/RJ) e José Dirceu (PT/SP), na Comissão de Ética da Câmara, em 8 de agosto de 2005, que foram transmitidos ao vivo pelas emissoras de TV.

O estilo considerado como "performático e teatral" de Jefferson ao narrar os acontecimentos chamava a atenção dos jornalistas e, segundo Guazina (2011), reforçou a divisão dramática nas funções dos personagens da notícia: vilões, bandidos e mocinhos que se enfrentam na arena política.
Jefferson acusou José Dirceu de chefiar um esquema de compra de votos na Câmara pela aprovação de matérias do Poder Executivo, que apelidou de Mensalão, e esse foi o ponto de partida da mídia para a eclosão do escândalo. De acordo com Lima (2004), a mídia promove um conjunto de construções simbólicas reunidas em torno de um tema, mantendo um núcleo central organizador.

\footnotetext{
“A televisão é o espaço, por excelência, de construção da cultura mítica no mundo contemporâneo. A mídia fabrica e emite os imaginários sociais. Da mesma forma que as sociedades ditas primitivas, o papel de manutenção e reprodução dos mitos era dos sacerdotes, feiticeiros, mágicos, hoje, esse lugar privilegiado é ocupado pela televisão e nela, sobretudo, pela narrativa melodramática" (Lima, 2004: 23).
}

O episódio que envolveu Roberto Jefferson e o ex-ministro José Dirceu demostra que, em determinadas situações, as atenções da mídia se voltam mais para as personagens do que 
para partidos e ideologias. O estudo da autora deste artigo sobre a construção de José Dirceu como personagem pela revista Veja, antes e depois do escândalo do Mensalão, demonstra isso. A publicação dedicou-lhe dez capas, de 2005 a 2014, tamanha a importância do personagem para sua narrativa política.

Durante a pesquisa, foi possível comprovar que a construção da personagem na política torna a cobertura midiática mais acessível à identificação do público por meio do recurso da dramatização. No contexto da disputa ideológica entre Veja e PT, José Dirceu é um alvo a ser atingido. Apontado como responsável de um ato supostamente ilícito, seria antagonista de valores morais defendidos pela revista, como a ética na política, uma exigência que permeia o senso comum da população, mais precisamente dos eleitores.

A descrição minuciosa de personagens é considerada por Motta (2013) uma estratégia argumentativa do jornalismo para gerar efeito de real e garantir que o destinatário da mensagem acredite que a história é verdadeira. Entre essas estratégias, estão as aspas com afirmações dos entrevistados ou fontes não identificadas, números e datas.

Nas matérias analisadas, encontramos a presença de elementos narrativos, descrição de episódios e de espaços físicos, das falas dos personagens e a caracterização psicológica de José Dirceu, sobressaindo sobre a sua atuação política.

Constatamos que os jornalistas que escreveram as matérias da Veja, no período que foi estudado, são narradores oniscientes (sabem o que se passa ao redor) e intrusos (dão opiniões sobre o que é narrado). As fontes são narradoras também e contribuem para a organização dos relatos de bastidores, onde o jornalista não pode estar. A negociação entre fontes e jornalistas durante a apuração faz parte da construção dos personagens, segundo Mesquita (2003). Isso justifica o que acontece com José Dirceu em Veja. A revista relata fragmentos da biografia do ex-ministro de acordo com suas necessidades editoriais. Portanto, o personagem não é real, é construído, é uma figura do discurso como também afirma Motta (2013).

Em todas as matérias analisadas, dilemas íntimos e morais dos personagens são expostos. Suas atitudes, estados emocionais, problemas e futuras soluções também ganham destaque. Sempre há comportamentos descritos que definem e revelam esses personagens. Frio, pragmático e sem limites pelo poder são as características de Dirceu que se destacam no enquadramento da revista. $\mathrm{O}$ conjunto das caracterizações nos levou a concluir que a função de José Dirceu como personagem é de um anti-herói trágico. A partir da definição de Vogler (2006), os anti-heróis trágicos são aqueles que cometem erros, mas não conseguem corrigir o dano, "ignoram advertências sensatas ou desafiam os códigos morais, achando que estão acima das leis divinas" (Vogler, 2006: 101).

Veja recobre de desconfiança a atuação política de José Dirceu, que era contrário à ditadura militar, desde o Movimento Estudantil de 68, quando a revista duvidou de sua capacidade 
como líder e o colocou como um dos responsáveis pelo episódio conhecido como "Batalha da Rua Maria Antônia”, em São Paulo, uma briga em praça pública de estudantes contra e a favor do regime.

As características de Dirceu destacadas pela revista durante a ditadura voltam a ganhar evidência em outras ocasiões, entre elas, em 2002, quando da possibilidade de Lula chegar à presidência da República e também no escândalo do Mensalão. A desconfiança se mantém no período pós-escândalo, quando a revista investiga as visitas que Dirceu recebe em seu quarto de hotel, em Brasília, em 2011, definindo-o como "O Poderoso Chefão", e considera que ele ainda tinha poder e influência sobre o PT e o governo naquele período e, durante a prisão, quando o acusa de receber privilégios na Penitenciária da Papuda, no Distrito Federal, em relação a outros presos.

De acordo com as análises das 10 edições, o destino de Dirceu é traçado por Veja: ele cometeu uma falha e não pode ser perdoado por isso. A revista considera a pena do ex-ministro branda, o fiscaliza e o expõe na prisão, para fins de sensacionalismo, que é contra a Lei de Execução Penal brasileira. Mesmo diante de um caso de corrupção cujos réus foram julgados e condenados, a cobertura não propõe melhorias ao sistema político e nem a possibilidade do político acusado se recuperar e voltar à sociedade.

Observou-se ao longo da pesquisa que esse padrão é seguido por outros veículos de mídia brasileiros. Os escândalos políticos precisam ser noticiados, pois são de interesse público, e às vezes envolvem recursos que deveriam ser repassados aos cidadãos. Mas as coberturas jornalísticas têm priorizado a personalização e o linchamento como estratégia comercial para a atrair audiência em detrimento às notícias que promovam as informações e o incentivo à participação popular nas decisões.

\section{Conclusão}

A partir da relação entre os temas democracia e confiança, tratada pelos autores referenciados neste artigo, concluímos que as expectativas criadas pela população ao eleger representantes diminuem de forma proporcional à ausência de respostas que os membros dos poderes Executivo e Legislativo precisam de dar à sociedade após eleitos. Diante das cobranças, que podem vir por meio de ativismo social ou da própria mídia, os políticos quase sempre correm riscos de perder a credibilidade e os votos, principalmente em situações de crise política ou econômica.

Eis um dos pontos cruciais para as reações dos eleitores: eles precisam de se informar sobre os candidatos que escolhem para que haja identificação com a plataforma de governo proposta ou de interesses. Miguel (2010) completa que grande parte dessas informações advém da mídia, mas todos os veículos possuem as suas preferências ideológicas e partidárias.

No Brasil, que viveu 20 anos de Ditadura Militar, o fim da censura e o fortalecimento dos órgãos fiscalizadores do Estado contribuíram com um cenário favorável para investigações jornalísticas sobre escândalos 
de corrupção. A concentração das acusações em pessoas sem a devida conclusão de inquérito e processo judicial pode causar danos irreversíveis aos políticos em sua credibilidade e reputação, além de quebrar a confiança dada pelos eleitores.

No jornalismo, principalmente na cobertura política, alguns reflexos das características do governo representativo podem ser percebidos, sendo um deles a personalização, considerado como valor-notícia por Traquina (2005). Baseado nesses estudos, a autora apresentou resultados de sua dissertação de mestrado, onde dissecou a construção do ex-ministro da Casa Civil do governo Lula, José Dirceu, como personagem da revista Veja, e constatou que a caracterização do personagem se deu de uma forma que provocasse a desconfiança do público sobre sua reputação.

A partir do momento em que o eleitor confere seu voto ao político, quase sempre se estabelece uma relação de confiança. Ao longo do tempo, quando as expectativas não são atendidas, há uma espécie de quebra dessa confiança com o eleitorado que se acentua ainda mais se os políticos se envolvem em escândalos, como desvios de recursos públicos ou de corrupção para obter ganhos pessoais ou partidários.

A medição de índices de desconfiança das pessoas, muito altos em instituições como o governo e o Congresso Nacional em comparação aos índices significativos de confiança nos veículos de comunicação, refletem duas situações: a população está recebendo informações negativas generalizadas da mídia sobre política, que atraem mais audiência; e a existência da frustração dos eleitores com os resultados práticos da atuação dos candidatos que elegeram.

De acordo com estudos analisados, o modelo democrático tradicional representativo permite que os políticos não sejam obrigados a realizar as vontades dos eleitores e favorece um distanciamento entre decisões de governo e a vontade popular. $\mathrm{O}$ que se percebe na construção das notícias é justamente isso: quem fala são os políticos, não os partidos ou a ideologia. Quando sucessivos escândalos são noticiados ou um deles tem uma longa cobertura, de acordo com Gomes (2007), eles podem ser espetacularizados e o público corre o risco de se ver mais como espectador do que como eleitor e cidadão.

Por isso, a tendência apresentada como ideal pelos autores é o desenvolvimento de um novo sistema democrático que privilegie a participação popular nos processos de decisão e também de monitoramento do uso dos recursos públicos.

\section{Referências bibliográficas}

Bucci, E. (2000). Sobre Ética e Imprensa. São Paulo: Companhia das Letras. Conti, M. S. (1999). Notícias do Planalto: A imprensa e Fernando Collor. São Paulo: Companhia das Letras.

Chandhoke, N. (2005). Revisiting the crisis of representantion thesis: the indian context. Democratization, 12, 308-330.

Entman, R. (1993). Framing: toward clarification of a fractured paradigm. Journal of Communication, 43, 51-58. 
Gomes, W. (2007). Transformações da Política na Era da Comunicação de Massa. São Paulo: Paulus.

Guazina, L. (2011). Jornalismo em busca de credibilidade: a cobertura adversária do Jornal Nacional no escândalo do Mensalão. Tese de Doutoramento em Comunicação Social. Universidade de Brasília, Brasil.

Lima, V. (2004). Cenários de Representação da Política, CR-P. In Rubim, A. A. C. (ed.), Comunicação e Política - Conceitos e Abordagens. São Paulo: UNESP.

Matos, C. (2008). Jornalismo e Política Democrática no Brasil. São Paulo: Publifolha.

Markun, P. (2004). O Sapo e o Príncipe: Personagens, fatos e fábulas do Brasil contemporâneo. Rio de Janeiro: Objetiva.

Mesquita, M. (2003). O Quarto Equívoco: $O$ poder dos media na sociedade contemporânea. Coimbra: Minerva.

Meyer, T. \& Hinchman, L. (2008). Democracia Midiática: Como a mídia coloniza a política. São Paulo: Edições Loyola.

Miguel, L. F. (2010). A mídia e o declínio da confiança na política. In Biroli, F. \& Miguel, L.F. (eds.). Mídia,
Representação e Democracia. Hucitec: São Paulo.

Moisés, J. \& Carneiro, G. (2008). Democracia, desconfiança política e insatisfação com o regime - o caso do Brasil. Opinião Pública, 14, 1-42.

Motta, L. G. (2013). Análise Crítica da Narrativa. Brasília: Editora Universidade de Brasília.

Nassif, L. (2003). O Jornalismo nos Anos 90. Futura: São Paulo.

O’Donnel, G. (1991). Democracia Delegativa?. Novos Estudos, 31, 25-40.

Rehbein, M. (2015). Noticiário Político: um diagnóstico da cobertura pela mídia impressa. In Adghirni, Z. L. (ed). Jornalismo e Poder Legislativo: Relações entre mídia e política no

Brasil. Curitiba: Aprris.

Rosavallon, P. (2008). Counter-democracy: Policy in a age of distrust. New York: Cambrigde University.

Thompson, J. (2002). O Escândalo Político: Poder e visibilidade na era da mídia. Rio de Janeiro: Vozes.

Traquina, N. (Org.) (1993). Jornalismo: Questões, teorias e histórias. Lisboa: Vega.

Traquina, N. (2005). Teorias do Jornalismo. Florianópolis: Insular.
Tuchman, G. (1978). Making News: A study in the construction of reality. New York: Free Press.

Tuchman, G. (1993). A Objetividade como Ritual Estratégico: uma análise das noções de objetividade dos jornalistas. In Traquina, N. (ed.) Jornalismo: Questões, teorias e histórias. Lisboa: Vega.

Vieira, A.P. R. (2015). A construção do personagem José Dirceu pela Revista Veja durante e após o escândalo do mensalão. Tese de Mestrado em Comunicação e Sociedade. Universidade de Brasília, Brasília.

Waisbord, S. (2000). Watchdog Journalism in South America: News, accountability and democracy. New York: Columbia University Press.

Warren, M. (1999). Democracy and Trust. Cambridge: Cambridge University Press.

Wolf, M. (1987). Teorias da Comunicação. Lisboa: Editorial Presença.

Vogler, C. (2006). A Jornada do Escritor. Rio de Janeiro: Nova Fronteira. 